\title{
Enhancing the English-Language Oral Skills of International Students through Drama
}

\author{
Chamkaur Gill ${ }^{1}$ \\ ${ }^{1}$ Bond University, Australia \\ Correspondence: Chamkaur Gill, School of Humanities, Faculty of Humanities and Social Sciences, Bond \\ University, Gold Coast 4229, Queensland, Australia. E-mail: cgill@bond.edu.au
}

Received: January 8, 2013 Accepted: February 4, 2013 Online Published: March 10, 2013

doi:10.5539/elt.v6n4p29 URL: http://dx.doi.org/10.5539/elt.v6n4p29

\begin{abstract}
Ten non-English-speaking-background students of Bond University were observed to identify the effects of drama on oral English. Over a period of twelve weeks (two hours per week), elements of their oral English communication were measured. The weeks were divided into four lots of three weeks each, with the first three weeks made up entirely of communicative non-drama-based (CNDB) lessons, weeks four to six comprising only communicative drama-based (CDB) methodology, weeks seven to nine reverting to CNDB methodology, and the final three weeks being made up of CDB strategies again. The hypothesis of this study was that all the participants would show improvement once CDB methodology was introduced and that, by the end of Week 12, their mean-scores would be higher than when they were first observed. The first part of the hypothesis was disproved for a majority of the participants, while the second part revealed positive findings for all ten.
\end{abstract}

Keywords: drama-based learning, communicative oral ESL, international university students

\section{Introduction}

International non-English-language-background students studying in English-speaking countries like Australia inevitably come up against the hurdle of having to use English orally in a variety of situations. Both they and their institutions share the responsibility of raising their performance-levels to the point where this hurdle is lowered or, preferably, removed. This is crucial if the learners are to succeed academically and socially in their host countries. Among the communicative-based strategies that can play a role in achieving this objective is drama. The primary objective of this study was to prove that such a strategy could assist learners improve their English-language speaking skills.

\subsection{Problems International Students Face with Spoken English}

Guiora (1972) theorizes that speaking is the most psychologically demanding of the four language skills. One of the challenges faced by international ESL students is expressing themselves clearly and fluently (Hellstén, 2002; Hellstén \& Prescott, 2004; Huang, 2005; Liu \& Jackson, 2008; Mak \& White, 1997; Mulligan \& Kirkpatrick, 2000; Sawir, 2005; Wong, 2004; Zhang \& Mi, 2009). Home-country schooling experiences indicate limited oral output or student participation, with classes being clearly teacher-centred (Erbaugh, 1990; Kim, 2004; Klinger, 2000; Rao, 2001). This results in limited abilities in spoken English, putting them at a disadvantage in English-speaking countries, where oral participation in English tends to be the norm during tutorials or discussions. They expect to improve once overseas and there is evidence to show that they do (Towell, Hawkins \& Bazergui, 1996; Segalowitz \& Freed, 2004) but, as Rossiter, Derwing, Manimtin and Thomson (2010) contend, "many ESL classes offer little or no explicit, focused instruction on the development of oral fluency skills" (p. 585), leading to limited development in speaking skills. Sometimes it has to do with learners' negative experiences and perceptions in relation to their teachers, the content, and learning and teaching materials $(\mathrm{Li}$, 2003). Lower-than-expected improvement could also be due to learning opportunities not being used effectively enough (Segalowitz \& Freed, 2004). For example, learners are sometimes reluctant to participate due to factors like anxiety and low proficiency in English (Liu \& Jackson, 2008). In addition, their opportunities to speak actively in overseas institutions are perhaps restricted to institutionalised classroom activities like answering questions, participating in discussions, taking part in seminars, and giving prepared speeches. Even if these activities are more communicative and student-centred than in their home-countries, they could be described as dissimilar to the interactional English outside the classroom (Springer \& Collins, 2008). Besides, it has been 
observed that not everyone participates equally during discussions and seminars (Warschauer, 1996). Those with greater proficiency in English tend to dominate (Liu \& Jackson, 2009), giving the reticent ones fewer opportunities to participate. Furthermore, classroom work and procedures can become predictable and mundane (see Small, Dodge \& Jiang, 1996, for research on interesting and boring learning situations), leading to a low inclination to speak in English, thereby limiting opportunities to engage in spoken English. In order to improve, learners must use as many occasions as possible to speak (Liu \& Jackson, 2008). "Students to a large extent learn to speak by speaking", according to Kagan $(1995$, p. 3). If a study done in Canada by Derwing, Munro and Thomson (2008) on migrant Mandarin and East Slavic speakers is anything to go by, it can be surmised that greater exposure to speaking and listening is necessary if learners' oral-language skills are to improve.

\subsection{Research in Drama Strategies}

Speaking readily associates itself with drama in language learning, yet there appears to be limited published quantitative research in the field. McCarthy and O'Keeffe (2004) refer to a variety of studies on the teaching of speaking but, interestingly, make no mention of drama as a pathway. As Kao and O'Neill (1998) observe, "conducting valid and reliable research about what is happening in drama-oriented language classrooms has been neglected by language teachers and researchers" (p. 35). A lot of literature on the benefits of drama tends to be philosophical, observational and instructional (Almond, 2005; Dougill, 1987; Holden, 1981; Maley \& Duff, 1982; Smith, 1984; Wessels, 1987), "based on intuition or experience, rather than on empirical evidence" (Kao \& O'Neil, 1998, p. 44). International studies which show the extent to which drama works (e.g., Gaudart, 1990; Miccoli, 2003; Stern, 1980; Stinson, 2007; Stinson \& Freebody, 2006a, 2006b; Ulas, 2008), are not widespread enough. A rare example of a synthesis of the two is Kao and O'Neill (1998). In a comprehensive literature review, Podlozny (2000) identifies only 80 experimental studies between the 1960s and the beginning of this century that look at the effects of drama. Of these, only 38 represent published material. Even here, not all deal with the development of spoken language. Also, while such studies indicate the value of drama to the development of English-language production skills, they are mainly restricted to children and generic groups (same nationality, language or ethnic group). In addition, there appears to be no formal research pertaining to the implementation of alternating methodology in which equal class-time is devoted to CNDB learning, and CDB learning for spoken ESL. This paper aims to contribute to research on the impact of drama on the oral English of multi-national university students (young and mature-age adults) from a variety of language backgrounds.

\subsection{The Benefits of Drama}

Drama can play an important role in developing learners' speaking abilities (Ashton-Hay, 2005; Ballantyne, Bain \& Packer, 1997; Di Pietro, 1987; Gill, 2007; Miccoli, 2003). There is spontaneous speech and although the spontaneity may create error-ridden language, "the lack of pressure to produce "correct" speech promotes confidence and fluency" (Kao \& O'Neil, 1998, p. 24). Fluency here refers to smoothness of flow when speaking rather than grammatical accuracy (see Chambers, 1997; Koponen \& Riggenbach, 2000; Riggenbach, 1991 for overviews of the term 'fluency'). Davies (1990) contends that:

Drama activities facilitate the type of language behaviour that should lead to fluency, and if it is accepted that the learners want to learn a language in order to make themselves understood in the target language, then drama does indeed further this end. (p. 96).

Vocabulary and grammar develop through the enacted situations (Erdman, 1991; Gill, 2004, 2007; O'Gara, 2008). At the same time, they exhibit more animated paralanguage and their voices become more expressive (Gill, 2004). This is particularly useful to students who suffer from 'social anxiety' (Schneier \& Welkowitz, 1996). They are shy and inhibited, lack confidence and self-esteem, and are anxious about taking risks with a foreign language (Gill, 2007). Risks include the danger of mispronunciation, e.g. faulty syllable length (Gill, 2004), thus causing a loss of face that, in turn can have a detrimental effect on the speaker (Goh, 1996). Through taking on make-believe roles that 'protect' them, the shyest students can improve their pronunciation (Erbaugh, 1990). The cover of fiction reduces the impact of unnerving situations (Brash \& Warnecke, 2009). Kao and O'Neill (1998) state that drama helps generate in-class conversation which "for many language learners, is their major source of learning to use the target language”. (p. 78). Learners are more receptive to the notion of oral interaction if mini-dramas or dialogue enactments are introduced in class (Felder, 1995). There is cooperative learning involving groups. Group-work, according to Long and Porter (1985) is more effective than traditional 'lockstep' methodology. It increases talking time in class. They estimate that in an EFL class comprising 30 students, speaking time for each student averages out to just one hour per year in a traditional system, but increases by more than 500 per cent where learning is group-work based. In a similar vein, Kagan (1995) suggests that an interactive session in class results in more language output in two minutes than in a 
non-interactive one in an hour. Drama allows learners to participate in wide-ranging oral interaction with a variety of language forms (Davies, 1990; Genesee, 1994; Long \& Porter, 1985).

\section{Method}

Eligibility criteria for participation in this research initiative were: Adults, IELTS scores of 5.5-6 and enrolled as under- or post-graduate students at Bond University in any of the four faculties and one institute. Participants were recruited through student email announcements, posters and Student Learning Support invitations. Students participated in a two-hour session each week for twelve weeks, making a total time-commitment of twenty-four hours. Classes were held from six to eight o'clock in the evening and dinner in the form of pizza and drinks was made available.

\subsection{Programme Structure}

The twelve weeks were subdivided into four components of three weeks (six hours) each. None of the students had had formal experience in the use of drama strategies in oral-English learning. The author of this paper was the intervention-facilitator and two native-speakers of English, both non-teaching employees of Bond University, observed the students in class at the end of each component.

The activities conducted in the four components were as follows (Table 1):

Table 1. CNDB and CDB Activities

\begin{tabular}{ll}
\hline Component & Activity \\
\hline Component One & \\
Weeks 1-3 (CNDB) & Listening comprehension, teacher-fronted discussions \\
\hline Component Two & Skits, improvisations, simulations, role-play, process-drama \\
Weeks 4-6 (CDB) & \\
\hline Component Three & Teacher-fronted discussions, speech-giving \\
\hline
\end{tabular}

Component Four

Weeks 10-12 (CDB) Improvisations, role-play, rehearsing and staging short plays created by students in groups

\subsection{Research Measures}

Research was conducted using a Repeated Measures (ABAB) methodology. The participants were observed in Weeks Three (Time One), Six (Time Two), Nine (Time Three), and Twelve (Time Four). The primary research instrument was a composite rating tool comprising twelve items representing core elements of communication, as follows:

The Speaker:

- Speaks clearly.

- Speaks at the right volume/projects voice.

- Speaks at the right speed.

- Speaks with correct sentence rhythm.

- Speaks with the right pitch/inflection/tone.

- Word-stress and syllables are correct.

- Speaks in understandable words and sentences.

- $\quad$ Speaks with adequate grammatical correctness.

- Holds the listener's attention.

- Makes appropriate eye-contact with the listener.

- Has appropriate body-language/stance.

- $\quad$ Avoids distracting movements and gestures. 
The elements and wording were adapted and combined with permission from the authors of two published instruments (Adams, 2004; Isaacs, 2008). The items were scored on a seven point Likert scale with response categories ranging from 1 (not well at all) to 7 (extremely well). The observers scored each participant and discussed ratings until they reached inter-rater reliability. Participants were randomly assigned to observers for scoring. The same score sheet was distributed to participants before the intervention started and at the conclusion of the program, for self-assessment purposes. The objective behind the rating tool was not to focus on each item specifically or individually but to get an overall picture of each participant alongside participation, quantity of speech, and levels of anxiety and confidence. To this end, four additional measures were used within the research. First, in addition to completing the rating instrument, the observers kept field notes. They recorded which participants volunteered speaking contributions at which points in the sessions and how their speech-acts transpired. The intervention-facilitator kept process notes and reflections and submitted these to the research team for analysis. Some of the sessions were video-recorded and elements of the recordings reviewed and transcribed for interpretation of the research results. Finally, a post-intervention meeting was conducted at the end of the course to solicit feedback from the students.

\subsection{The Participants}

The call for participation drew twenty-one female and two male undergraduate and postgraduate students from diverse cultures and countries. However, data-analysis could be conducted for only ten of them. This was because six (participants B, F, G, J, O, R) dropped out immediately after the first session, another two (participants $\mathrm{H}$ and $\mathrm{U}$ ) attended only two sessions, while one (participant $\mathrm{P}$ ) left after four sessions, as indicated in table 2 below. Participants A and I were considered unsuitable because, in addition to only five and six attendances respectively, they missed crucial components of the course. Two others ( $\mathrm{S}$ and $\mathrm{T}$ ) were not considered because of incomplete observer-rating and self-assessment data respectively. The ten $(\mathrm{C}, \mathrm{D}, \mathrm{E}, \mathrm{K}, \mathrm{L}$, $\mathrm{M}, \mathrm{N}, \mathrm{Q}, \mathrm{V}, \mathrm{W}$ ) who were left were present for all four observations and completed the required two self-assessments, thereby yielding the data sought.

Table 2. Participants' Gender, Country of Origin and Attendance across the 12 Weeks

\begin{tabular}{|c|c|c|c|c|c|c|c|c|c|c|c|c|c|c|}
\hline ID & Gender & Country & W1 & W2 & $\begin{array}{l}\text { W } \\
3\end{array}$ & W4 & W5 & W6 & W7 & W8 & W9 & W10 & W11 & W12 \\
\hline A & $\mathrm{F}$ & China & A & $\mathrm{P}$ & $P$ & A & $\mathrm{P}$ & $\mathrm{P}$ & A & A & A & $\mathrm{P}$ & A & A \\
\hline B & $\mathrm{F}$ & China & $\mathrm{P}$ & A & A & A & A & A & A & A & A & A & A & A \\
\hline $\mathrm{C}$ & $\mathrm{F}$ & Japan & $\mathrm{P}$ & $\mathrm{P}$ & $\mathrm{P}$ & $\mathrm{P}$ & $\mathrm{P}$ & $\mathrm{P}$ & A & $\mathrm{P}$ & $\mathrm{P}$ & $\mathrm{P}$ & $\mathrm{P}$ & $\mathrm{P}$ \\
\hline D & $\mathrm{F}$ & China & $\mathrm{P}$ & A & $\mathrm{P}$ & $\mathrm{P}$ & $\mathrm{P}$ & $\mathrm{P}$ & $\mathrm{P}$ & $\mathrm{P}$ & $\mathrm{P}$ & $\mathrm{P}$ & $\mathrm{P}$ & $\mathrm{P}$ \\
\hline E & $\mathrm{F}$ & China & $\mathrm{P}$ & $\mathrm{P}$ & $\mathrm{P}$ & $\mathrm{P}$ & A & $\mathrm{P}$ & $\mathrm{P}$ & $\mathrm{P}$ & $\mathrm{P}$ & $\mathrm{P}$ & $\mathrm{P}$ & $\mathrm{P}$ \\
\hline $\mathrm{F}$ & $\mathrm{F}$ & China & $\mathrm{P}$ & A & A & A & A & A & A & A & A & A & A & A \\
\hline G & $\mathrm{F}$ & China & P & A & A & A & A & A & A & A & A & A & A & A \\
\hline $\mathrm{H}$ & $\mathrm{F}$ & China & $\mathrm{P}$ & $\mathrm{P}$ & A & A & A & A & A & A & A & A & A & A \\
\hline I & $\mathrm{F}$ & China & A & A & A & A & $\mathrm{P}$ & A & $\mathrm{P}$ & $\mathrm{P}$ & A & $\mathrm{P}$ & $\mathrm{P}$ & $\mathrm{P}$ \\
\hline $\mathrm{J}$ & $\mathrm{F}$ & China & $\mathrm{P}$ & A & A & A & A & A & A & A & A & A & A & A \\
\hline K & $\mathrm{F}$ & Malaysia & $\mathrm{P}$ & $\mathrm{P}$ & $\mathrm{P}$ & $\mathrm{P}$ & $\mathrm{P}$ & $\mathrm{P}$ & $\mathrm{P}$ & $\mathrm{P}$ & $\mathrm{P}$ & $\mathrm{P}$ & A & $\mathrm{P}$ \\
\hline $\mathrm{L}$ & $\mathrm{F}$ & Malaysia & $\mathrm{P}$ & $\mathrm{P}$ & $\mathrm{P}$ & $\mathrm{P}$ & $\mathrm{P}$ & $\mathrm{P}$ & $\mathrm{P}$ & $\mathrm{P}$ & $\mathrm{P}$ & $\mathrm{P}$ & $\mathrm{P}$ & $\mathrm{P}$ \\
\hline M & $\mathrm{F}$ & Malaysia & $\mathrm{P}$ & $\mathrm{P}$ & $\mathrm{P}$ & $\mathrm{P}$ & $\mathrm{P}$ & $\mathrm{P}$ & $\mathrm{P}$ & $\mathrm{P}$ & $\mathrm{P}$ & $\mathrm{P}$ & $\mathrm{P}$ & $\mathrm{P}$ \\
\hline $\mathrm{N}$ & $\mathrm{F}$ & Malaysia & $\mathrm{P}$ & $\mathrm{P}$ & $\mathrm{P}$ & $\mathrm{P}$ & A & $\mathrm{P}$ & $\mathrm{P}$ & $\mathrm{P}$ & $\mathrm{P}$ & $\mathrm{P}$ & $\mathrm{P}$ & $\mathrm{P}$ \\
\hline $\mathrm{O}$ & F & China & $\mathrm{P}$ & A & A & A & A & A & A & A & A & A & A & A \\
\hline $\mathrm{P}$ & M & Qatar & $\mathrm{P}$ & $\mathrm{P}$ & $\mathrm{P}$ & $\mathrm{P}$ & A & A & A & A & A & A & A & A \\
\hline Q & M & Pakistan & $\mathrm{P}$ & A & $\mathrm{P}$ & $\mathrm{P}$ & $\mathrm{P}$ & $\mathrm{P}$ & $\mathrm{P}$ & $\mathrm{P}$ & $\mathrm{P}$ & $\mathrm{P}$ & $\mathrm{P}$ & $\mathrm{P}$ \\
\hline $\mathrm{R}$ & $\mathrm{F}$ & China & $\mathrm{P}$ & A & A & A & A & A & A & A & A & A & A & A \\
\hline S & $\mathrm{F}$ & China & $\mathrm{P}$ & P & $\mathrm{P}$ & A & A & $\mathrm{P}$ & $\mathrm{P}$ & A & P & $\mathrm{P}$ & $\mathrm{P}$ & $\mathrm{P}$ \\
\hline $\mathrm{T}$ & $\mathrm{F}$ & China & $\mathrm{P}$ & $\mathrm{P}$ & $\mathrm{P}$ & $\mathrm{P}$ & $\mathrm{P}$ & $\mathrm{P}$ & A & A & $\mathrm{P}$ & $\mathrm{P}$ & A & A \\
\hline $\mathrm{U}$ & $\mathrm{F}$ & China & $\mathrm{P}$ & A & $\mathrm{P}$ & A & A & A & A & A & A & A & A & A \\
\hline V & $\mathrm{F}$ & China & $\mathrm{P}$ & $\mathrm{P}$ & $\mathrm{P}$ & A & A & $\mathrm{P}$ & A & A & $\mathrm{P}$ & $\mathrm{P}$ & A & $\mathrm{P}$ \\
\hline W & $\mathrm{F}$ & China & $\mathrm{P}$ & $\mathrm{P}$ & $\mathrm{P}$ & A & $\mathrm{P}$ & $\mathrm{P}$ & A & $\mathrm{P}$ & $\mathrm{P}$ & $\mathrm{P}$ & $\mathrm{P}$ & $\mathrm{P}$ \\
\hline
\end{tabular}

Note: $\mathrm{F}=$ Female, $\mathrm{M}=$ Male, $\mathrm{W} 1$ to $\mathrm{W} 12=$ Week 1 to Week $12, \mathrm{~A}=$ Absent, $\mathrm{P}=$ Present 


\section{Results}

Quantitative results were analysed using SPSS version 18, a quantitative data analysis tool.

\subsection{Performance Ratings}

The observer and self-assessment scores were averaged across all data points. The mean observer scores for each participant can be seen in Table 3 while the self-assessment data is in Table 4.The averaged mean observer and self-assessment scores can be found in Table 5.

Table 3. Mean Observer Ratings over Four Observation Points for each Participant

\begin{tabular}{|c|c|c|c|c|c|}
\hline Participant & $\begin{array}{lr}\text { Mean } & \text { Observer } \\
\text { Scores } & \text { Time } \\
\text { One } & \end{array}$ & $\begin{array}{l}\text { Mean Observer } \\
\text { Scores Time Two }\end{array}$ & $\begin{array}{l}\text { Mean } \\
\text { Scores } \\
\text { Three }\end{array}$ & $\begin{array}{r}\text { Observer } \\
\text { Time }\end{array}$ & $\begin{array}{l}\text { Mean Observer } \\
\text { Scores Time Four }\end{array}$ \\
\hline $\mathrm{C}$ & 4.16 & 5.50 & 5.75 & & 6.66 \\
\hline D & 4.16 & 5.33 & 4.98 & & 6.23 \\
\hline $\mathrm{E}$ & 3.58 & 4.39 & 4.08 & & 5.66 \\
\hline K & 4.25 & 3.83 & 4.75 & & 6.23 \\
\hline L & 3.91 & 2.50 & 5.00 & & 6.16 \\
\hline M & 5.00 & 5.00 & 4.50 & & 6.00 \\
\hline $\mathrm{N}$ & 4.83 & 4.16 & 5.33 & & 7.00 \\
\hline Q & 5.83 & 5.16 & 5.00 & & 5.91 \\
\hline V & 4.50 & 5.58 & 6.25 & & 6.33 \\
\hline W & 3.25 & 2.50 & 4.16 & & 6.16 \\
\hline
\end{tabular}

Table 4. Mean Self-assessment Scores for each Participant in Time One and Time Two

\begin{tabular}{llll}
\hline Participant & $\begin{array}{l}\text { Mean Self-Assessment } \\
\text { Time One }\end{array}$ & $\begin{array}{l}\text { Scores } \\
\text { Two }\end{array}$ & $\begin{array}{l}\text { Mean Self-Assessment Scores Time } \\
\text { Two }\end{array}$ \\
\hline C & 3.16 & 5.00 & \\
D & 3.91 & 5.33 & \\
E & 5.91 & 6.00 & \\
K & 3.75 & 4.82 & \\
L & 3.40 & 3.25 & \\
M & 3.58 & 4.56 & \\
N & 4.08 & 4.66 & \\
Q & 4.25 & 4.75 & \\
V & 5.83 & 6.08 & \\
W & 3.83 & 3.75 & \\
\hline
\end{tabular}

Table 5. Averaged Mean Observer and Self-assessment Scores for each Participant over the 12-Week Period

\begin{tabular}{lll}
\hline Participant & Mean Observer Scores & Mean Self-Assessment Scores \\
\hline C & 5.52 & 4.08 \\
D & 5.18 & 4.62 \\
E & 4.43 & 5.96 \\
K & 4.77 & 4.29 \\
L & 4.39 & 3.33 \\
M & 5.13 & 4.07 \\
N & 5.33 & 4.37 \\
Q & 5.48 & 4.50 \\
V & 5.67 & 5.96 \\
W & 4.02 & 3.79 \\
\hline
\end{tabular}




\subsection{Theme Analyses of Observer and Facilitator Notes}

The observer notes were analysed using qualitative data interpretation software called NVIVO 8. Two levels of analyses were undertaken; at level one, general themes were identified and at level two, data was coded at these themes. The themes noted were (i) classroom atmosphere and students' reactions and (ii) improvements.

\subsubsection{Classroom Atmosphere and Students' Reactions}

The classroom atmosphere went from relatively quiet, with limited verbal involvement by the participants in the first three weeks (CNDB - Component One) to an increasingly greater quantity of speech, with greater interaction between participants, from Weeks Four to Six (CDB - Component Two). This was followed by reduced oral output and interaction between Weeks Seven and Nine (CNDB - Component Three), though noticeably more than during Component One, and finally, higher levels of spoken interaction from Weeks Ten to Twelve (CDB - Component Four). This increased oral output appears to point to the influence of drama strategies. As Hawkins (1991) puts it, play-acting "gives rise to a torrent of speech practice" (p. 124). While the students were seated and generally less active or participative during the teacher-fronted lessons in Components One and Three, they were more animated and mobile during the acting-out of scenes in Components Two and Four. Descriptions ranged from 'there was lots of laughter' to 'enjoyment of process' particularly from Component Two onwards.

The observers also noticed increased cooperation among the group members and made comments such as 'gentle hum of cooperation and planning' and 'observed empathy and emotional attachment to fellow group members'. Heitzmann (2009) suggests that the greater the cooperation between peers, the more conducive the environment for learning. Additionally, the observers noted that as the weeks went by, the students had begun 'ignoring teacher/researchers' as compared to the initial stage when they appeared cautious because of the presence of the two observers. They seemed to have gone from being "inhibited by the surveillance of others" (Latané, 1981, p. 343 ) to displaying lower anxiety despite the presence of the observers, particularly during the CDB phases in the second and fourth components of the course. The CNDB units of the course, especially during Component Three, were also generally stress-free but the sense of being comfortable was more evident amongst most of the participants during the drama sessions. Brash and Warnecke (2009) suggest that it is possible that drama gives students a sense of security, allowing them to experiment with personal experiences, be less afraid of being constantly stopped to have their errors corrected by the teacher, use English contextually, and increase their motivation and confidence. The food and drink supplied also helped create a relaxed atmosphere, with the participants free to get up and go to the food-table as they wished, thus creating a learning environment that reflected authentic, real-world scenarios and encouraging participation in a non-threatening environment.

One observer noted that, although the students showed signs of being 'quite interested in the proceedings', they seemed 'embarrassed' in the earlier sessions, while the facilitator stated that 'many of the students tended to wait for me to ask them questions before they answered', very much in keeping with the characteristic cultural traits Asian students tend to display (Gill, 2004; Goh, 1996, 2002). All this changed with the introduction of drama. The facilitator noted that 'more enthusiasm (was) displayed during the drama sessions, perhaps because of the fun factor'. There was certainly more laughter and excitement during the drama sessions than in the non-drama ones, with paralanguage and extended sentences in English clearly evident. There was a greater willingness to produce interactive oral English during the CDB classes in Components Two and Four, when the teacher took a non-intrusive stance. Students are generally more inclined to participate in discourse once the teacher stops being the dominant figure (Di Pietro, 1987; Reeve, Bolt \& Cai, 1999). In these sessions, one observer noted that, 'students appeared to let their guard down and seemed uninhibited by concerns about pronunciation and grammar'. They interacted orally in communicative English with each other as they discussed issues, voiced personal opinions of agreement/disagreement, negotiated solutions, made inquiries, provided explanations, and established points-of-view with minimum dependence on the facilitator. In brief, they were participating in the sort of effective learning environment in which "the learner rather than the language or indeed the teacher is at the centre of the learning process" (Davies, 1990, p. 97).

\subsection{Improvements}

The observers noted several improvements in the participants across the twelve weeks. These can be categorised under improvements in attitudes and performance.

\subsubsection{Improvements in Attitudes and Performance}

While the students' oral interaction with the facilitator and each other remained limited in the first three weeks (CNDB teaching), it was noted that they became increasingly relaxed and inhibitions appeared to have been 
reduced' during the drama sessions. One of the observers noted that 'all the groups went on and on oblivious to the audience and into acting'. Kao and O'Neill (1998) state that drama gives students a sense of ownership over an activity and this helps increase dialogue. The observers also noted that the students were more willing to participate during the second round of CNDB teaching, 'requiring minimal educator instructions' and there was a 'full immersion in each topic of discussion'. This perhaps suggests that the preceding CDB component had helped create a more convivial environment that flowed over into Component Three. Increased oral output was especially evident when they found the topics interesting. For example, in Week Eight (Component Three), although the class had reverted to the non-drama format, there was greater oral output during a protracted discussion on the supernatural, the unexplained and religion. When topics create a sense of excitement, there is heightened motivation and receptivity (Barkhuizen, 1998). Where there is motivation, there is productivity (Ryan and Deci, 2000). Having said that, it would have been interesting to see how participants might have reacted to such topics in the first CNDB component, before drama was introduced, given the notion that unpredictability prevents boredom (Small, et al, 1996). Still, it was probably a combination of the novelty-factor and the relaxation-enhanced atmosphere created by drama in the preceding component that helped produce more speech.

It was further noted that the students' confidence grew; they were more assertive and were 'voicing their opinions and ideas' voluntarily. Their group-dynamics showed increasing signs of improvement as the drama sessions progressed during Components Two and Four. The participants were willing to work with each other in sharing ideas and helping one another in developing topics and play-scenes with the instructor's guidance. Such discussions "certainly increase the amount of individual student talking time." (Davies, 1990, p. 90). Several performance-improvements on the production of English, maintaining eye-contact, and the use of appropriate humour were noted by the observers from Component Two onwards and particularly during the drama sessions. They produced longer sentences in communicative English and exhibited a broader range of emotions during oral interactions. It was noted that there were appropriate turn-taking moments and interruptions in English conversations; as summarized by one observer, there was 'shared contribution, equitable, distributed conversation' and it was also noted that the students 'demonstrated comprehension of one another'. Furthermore, the observers noted by the end of the sessions that all conversations were in English, as compared to Component One when the students spoke in their native-tongues on a number of occasions during discussions. The observers found their English to be listener-friendly in the sense that they did not have to watch them intently or strain to understand what the participants were saying as they spoke. It may be argued that this was because the observers had got used to the subjects' speech-styles over time, but this was unlikely as observation occurred only four times and that too with breaks of two weeks between each. Of particular interest was the fact that they were less worried about a loss of face, something that confronts many people of Asian backgrounds (Goh, 1996, 2002). This was evidenced by the fact that they were less conscious about speaking excitedly, loudly or using larger gestures.

\section{Discussion}

An analysis of the quantitative rating scales indicated that, while the observers identified varying levels of performance during the course, they perceived a notable increase in the oral English skills of the students at the end of the twelve weeks. The majority of the participants also felt that they had improved.

\subsection{Observers' Ratings}

While the scores of C, D, E and V improved at the end of Week Six (Time Two), those of K, L, N, Q and W dropped. In the case of M, the mean-score at Time Two remained the same as Time One. In total, therefore, six of the ten selected participants observed were found to have either scored lower or not improved at the end of the first three weeks of CDB methodology, thus disproving the first part of the hypothesis that all the participants' oral communicative English would improve with the introduction of CDB methodology. Perhaps it was because of communication apprehension arising from having to take part in unfamiliar activities in a language distant from their own (Mak \& White, 1997) or because of cultural factors which made them view such process-oriented activities as "playful wastes of time." (Erbaugh, 1990, p. 18); it may have been that such methodology did not appeal to them academically, despite the fact that they were aware from the start that it would be introduced in Week Four. They might have found drama confronting and perhaps were anxious about being watched. According to Taylor et al (2010), observation can result in states of anxiety, which can affect performance negatively. The first part of the hypothesis was further negated by Q's score, which dropped a little further in Time Three (CNDB methodology). It is possible that the preceding CDB methodology had failed to inspire him and/or that his motivation to participate in this second CNDB phase was starting to wane due to its boredom-creating predictability (Small, et al, 1996). D, E and M, too, declined in Time Three, perhaps also due to a drop in motivation. Only $\mathrm{C}$ and $\mathrm{V}$ had progressively higher scores over the four observation times (Table 3). 
This consistent improvement suggests that they, of the ten, had the most positive outlook towards the twelve-week course.

The second part of the hypothesis was borne out by observer-ratings at the end of Week Twelve (Time Four), when all ten participants received higher scores than when they were first observed. In fact, the scores here were the highest of all their ratings. Such results suggest that the observers considered their communicative oral English to have improved. The scores also give credence to the possibility that the enhancement was an outcome of the implementation of CDB methodology. $\mathrm{N}$ was particularly outstanding in that she scored a maximum of 7 , with $\mathrm{C}$ a close second (6.66). Six others (D, K, L, M, V, W) all scored 6 and higher. The remaining two (E and Q) had scores in the high fives. In all likelihood, the majority had eventually found drama enjoyable and had become less inhibited about oral communication via this medium. As Barkhuizen (1998) suggests, enjoyment creates attitudes that result in heightened motivation and receptivity. Having said that, it should be noted that Q's mean-score was only slightly higher than in Time One, suggesting that drama strategies may have played a less meaningful part in his oral communication performance, compared to the rest. Overall though, the possible positive impact of drama on their performance can be seen by comparing the difference between the observer-scores of Time One and Time Two with the difference between the observer-scores at Time Three and Time Four (Table 6). Eight of them did better in the latter, suggesting that they had finally warmed to drama-methodology. The difference between Time Three and Time Four for $\mathrm{C}$ and $\mathrm{V}$ was lower than the difference between Time One and Time Two, surprising considering their progressive improvement over the twelve weeks. Perhaps this was because the other eight participants had become much more active and out-spoken, resulting in $\mathrm{C}$ and $\mathrm{V}$ being less dominant and not monopolising speaking-time as much as they had earlier in the course.

Table 6. Comparison of Difference between Time One and Time Two and Difference between Time Three and Time Four Observer-scores

\begin{tabular}{lll}
\hline Participant & $\begin{array}{l}\text { Difference between } \\
\text { Observer-scores at Time } \\
\text { One and Time Two }\end{array}$ & $\begin{array}{l}\text { Difference between } \\
\text { Observer-scores at Time } \\
\text { Three and Time Four }\end{array}$ \\
\hline C & +1.34 & +0.91 \\
D & +1.17 & +1.25 \\
E & +0.81 & +1.58 \\
K & -0.42 & +1.48 \\
L & -1.41 & +1.16 \\
M & 0.00 & +1.50 \\
N & -0.67 & +1.67 \\
Q & -0.67 & +0.91 \\
V & +1.08 & +0.08 \\
W & -0.75 & +2.00 \\
\hline
\end{tabular}

\subsection{Participants'Self-Assessment Ratings}

Except for L and W, all the participants rated themselves higher in Time Two (Table 4) of the self-assessment ratings. Perhaps L, being Malay, was keen to avoid self-praise (Awang, Maros \& Ibrahim, 2012), while W's Chinese background possibly stressed personal modesty (Erbaugh, 1990). The improved scores of the others may possibly have been the result of believing that exposure to CDB methodology had given them more speaking opportunities, thereby improving their communicative oral English through increased use.

\subsection{Increased Observer and Self-Assessment Scores}

One possible explanation for the increase in observer (for all) and self-assessment (excluding L and W) scores at the end of the twelve weeks could be that the participants had always had it in them to perform better, but needed the sort of environment that CDB lessons provided for them to "open up" (Gill, 2000). It is also probable that drama had helped them overcome, as Stern (1980) observed, psychological obstacles like limited motivation and self-esteem, a lack of empathy for English, and a fear of rejection. They appeared to have become more confident about speaking up in class. Improvisations and role-play gave them opportunities not only to speak spontaneously and expressively, but also to use body-language for effect. However, one should not discount the possibility that these developments could also have been because the participants were becoming 
increasingly comfortable with (i) the communicative approach (ii) drama strategies (iii) the format of the course (iv) each other (v) the instructor and (vi) the observers, thereby becoming less inhibited and participating more extensively as the course proceeded.

\subsection{Comparing Observer and Self-Assessment Scores}

Eight participants' self-assessment average ratings were lower than the average ratings of the observers (Table 5). This, as mentioned above, may have been due to inherent modesty. $\mathrm{E}$ and $\mathrm{V}$ went against the trend by rating themselves higher (average mean-score 5.96 each) than the observers did (average mean-score 4.43 and 5.66 respectively). They were both very active in class and appeared to be very confident and more inclined to take risks with their spoken English. Liu and Jackson (2008) postulate that such learners tend to rate themselves quite highly. This is probably why their self-assessment mean-scores were relatively high in both Time One and Time Two (Table 4). In addition, even though eight participants rated themselves higher at Time Two of the self-assessment scores (Table 4), the difference in their scores between Time One and Time Two was somewhat lower than the difference in the observer-ratings between Time One and Time Four (Table 7). This suggests that the observers had better opinions of them at the end of the course than the participants did of themselves. Only Q's self-rating was higher than that given by the observers. Whether it was because he was the only male, a postgraduate, and a relatively capable speaker with an average observer-mean-score of 5.47 (Table 5) are matters for debate.

Table 7. Difference between Time 1 and Time 2 Self-assessment Scores and Time 1 and Time 4 Observer Scores

\begin{tabular}{lcc}
\hline Participant & $\begin{array}{c}\text { Self-assessment-scores } \\
\text { (Difference between Time 1 \& Time 2) }\end{array}$ & $\begin{array}{c}\text { Observer-scores } \\
\text { (Difference between Time 1 \& Time 4) }\end{array}$ \\
\hline C & +1.84 & +2.50 \\
$\mathrm{D}$ & +1.42 & +2.07 \\
$\mathrm{E}$ & +0.09 & +2.08 \\
$\mathrm{~K}$ & +1.07 & +1.98 \\
$\mathrm{~L}$ & -0.15 & +2.25 \\
$\mathrm{M}$ & +0.98 & +1.00 \\
$\mathrm{~N}$ & +0.58 & +2.17 \\
$\mathrm{Q}$ & +0.50 & +0.08 \\
$\mathrm{~V}$ & +0.25 & +1.83 \\
$\mathrm{~W}$ & -0.08 & +2.91 \\
\hline
\end{tabular}

\section{Conclusion}

The first part of our hypothesis, that all the participants' oral English communication would improve as soon as CDB methodology was implemented, was rejected. This could possibly have been because (a) drama did not appeal to most of the participants for a variety of reasons and (b) the timeframe of 6 hours in the first CDB phase was too short for them to adjust to drama, a methodology which was uncommon or unfamiliar to them. The second part, that their mean-scores would show improvement at the end of the course, was accepted. Having said that, the quantitative data did not provide substantive evidence to ascertain whether any extra attention paid to international students would enhance functional English or whether drama-based pedagogy was especially efficacious. In order to assess the degree of the impact of drama on international students generally, the researchers looked to the qualitative data. In addition to observational comments by the facilitator and the observers, written feedback from six students gave an overall 'thumbs-up' to CDB teaching, with positive comments about having had more speaking opportunities, gaining confidence, being comfortable and therefore finding it easier to speak, understanding different accents, and appreciating the way the classes were structured.

In conclusion, it is fair to state that the outcomes of this experiment do not represent anything approaching a definitive finding about the value of drama to oral-English development. One of the reasons for caution is the size of the group that was studied. Data from ten subjects is far too small to make claims that drama works across the board. Another limitation was the length of the course. It is difficult to assume that a sum-total of twenty-four hours is sufficient to produce unshakeable evidence that EFL students' spoken English improves more through exposure to $\mathrm{CDB}$ than to CNDB methodology. The ABAB format was too short to compare the two methodologies or come up with conclusive attestation to their effects. Perhaps it might have been useful to follow an ABBA format instead, which would have given the participants an unbroken stretch of six weeks of 
drama. That way, we might have had a more definite comparison between the first and last three weeks. In other words, the CNDB methodology sessions in Weeks One to Three and Weeks Ten to Twelve could have been viewed as pre-test and post-test periods respectively, to determine the extent to which the intervention of six continuous weeks of drama benefited the participants. In addition, there was limited feedback arising from the final, post-intervention meeting. This was because the meeting was non-compulsory and therefore, not everyone attended. The chances of observer-subjectivity, too, cannot be discounted. Observer bias is not an unknown phenomenon (Hoyt \& Kerns, 1999), not to mention inadvertent errors, as evidenced by the omission of rating data for participant S. Perhaps the presence of more than two observers might have produced even more reliable data.

Such reasons are purely speculative, of course, as there was no concrete evidence to validate them. However, as limited as this study may be, it is hoped that it will prove useful as a basis for further research on the impact of drama on the spoken English of international ESL university students.

\section{Acknowledgement}

The author would like to acknowledge the support and advice provided by the Office of Teaching and Learning, Bond University, Gold Coast, Australia, particularly in relation to the data presented in this article.

\section{References}

Adams, K. (2004). Modelling success: Enhancing international postgraduate students' self-efficacy for research seminar presentations. Higher Education Research and Development, 23(2), 115-130. http://dx.doi.org/10.1080/0729436042000206618

Almond, M. (2005). Teaching English with drama. London: Modern English Publishing Ltd.

Ashton-Hay, S. (2005). Drama: Engaging all learning styles. Paper presented at the $9^{\text {th }}$ International INGED (Turkish English Education Association) Conference, 20-22 October, 2005, Economics and Technical University, Ankara Turkey. Retrieved from http://www.eprints.qut.edu.au/12261/

Awang, S., Maros, M., \& Ibrahim, N. (2012). Malay values in intercultural communication. International Journal of Social Science and Humanity, 2(3), 201-205. Retrieved from http://www.ijssh.org/papers/96-CH219.pdf

Ballantyne, R., Bain, J., \& Packer, J. (1997). Reflecting on university teaching: Academics' stories. Canberra: Australian Government Publishing Service.

Barkhuizen, G. P. (1998). Discovering learners' perceptions of ESL classroom teaching/learning activities in a South African context. TESOL Quarterly, 31(1), 85-107. http://dx.doi.org/10.2307/3587903

Brash, B., \& Warnecke, S. (2009). Shedding the ego: Drama-based role-play and identity in distance language tuition. Language Learning Journal, 37(1), 99-109. http://dx.doi.org/doi:10.1080/09571730902717661

Chambers, F. (1997). What do we mean by fluency? System, 25(4), 535-544. http://dx.doi.org/10.1016/S0346-251X(97)00046-8

Davies, P. (1990). The use of drama in English language teaching. TESL Canada Journal, 8(1), 87-99. Retrieved from www.teslcanadajournal.ca/index.php/tesl/article/viewFile/581/412

Derwing, T. M., Munro, M. J., Thomson, R. I. (2008). A longitudinal study of ESL learners' fluency and comprehensibility development. Applied $\quad$ Linguistics, $\quad 29(3), \quad 359-380$. http://dx.doi.org/doi:10.1093/applin/amm041

Di Pietro, R. J. (1987). Strategic interaction: Learning languages through scenarios. Cambridge: Cambridge University Press.

Dougill, J. (1987). Drama activities for language learning. London: Macmillan Publishers.

Erbaugh, M. S. (1990). Taking advantage of China's literary tradition in teaching Chinese students. The Modern Language Journal, 74(1), 15-27. http://dx.doi.org/10.1111/j.1540-4781.1990.tb02548.x

Erdman, H. (1991). Conflicts of interest: Bringing drama into the elementary foreign language classroom. Youth Theatre Journal, 5(3), 12-14.

Felder, R. M. (1995). Learning and teaching styles in foreign and second language education. Foreign Language Annals, 28(1), 21-31. http://dx.doi.org/10.1111/j.1944-9720.1995.tb00767.x

Gaudart, H. (1990). Using drama techniques in language teaching. In S. Anivan (Ed.), Language Teaching Methodology for the Nineties (pp. 230-249). Anthology Series 24. Singapore: Regional Language Centre. 
Genesee, F. (1994). Integrating language and content: Lessons from immersion. NCRCDSLL Educational Practice Reports, Center for Research on Education, Diversity and Excellence, UC Berkeley. Retrieved from http://escholarship.org/uc/item/61c8k7kh

Gill, C. (2000). Getting language learners to 'open up'. Australian Language Matters, 8(2), 7-8.

Gill, C. (2004). Drama as a means of improving the advocacy skills of non-English-speaking students. Retrieved from http://epublications.bond.edu.au/chamkaur_gill/2

Gill, C. (2007). Motivating English-language learners through drama techniques. In S. H. Saw, H. P. Lim, C. T. Chan, P. Vijayaratnam, S. John, \& E. N. Ding, E. N. (Eds.), Special Issue on Teaching and Learning 2007, (pp. 43-51). Subang Jaya: INTI Publishing House.

Goh, B. C. (1996). Negotiating with the Chinese. Aldershot: Dartmouth Publishing Company.

Goh, B. C. (2002). Law without lawyers, justice without courts. Aldershot: Ashgate Publishing.

Guiora, A. Z. (1972). Construct validity and transpositional research: Toward an empirical study of $\begin{array}{lllll}\text { psychoanalytic concepts. } & \text { Comprehensive }\end{array}$ http://dx.doi.org/10.1016/0010-440X(72)90019-3

Hawkins, B. (1991). Back to back: Drama techniques and second language acquisition. Die Neueren Sprachen, 90(2), 119-136. Retrieved from http://www.fachportal-paedagogik.de/fis_bildung/suche/fis_set.html?FId=288248

Heitzmann, J. (2009). The influence of the classroom climate on students' motivation. In R. Lugossy, J. Horvàth, \& M. Nikolov (Eds.), UPRT 2008: Empirical Studies in English Applied Linguistics (pp. 207-224). Pécs: Lingua Franca Csoport. Retrieved from www.elib.hu/07500/07558/07558.pdf\#page=213

Hellstén, M. (2002). Students in transition: Needs and experiences of international students in Australia. New times new approaches: Conference proceedings. $16^{\text {th }}$ Australian International Education Conference: Hotel Grand Chancellor Hobart, Tasmania, 30 September-4 October, 2002. Retrieved from www.trove.nla.gov.au/work/153101889?versionld=166855365

Hellstén, M., \& Prescott, A. (2004). Learning at university: The international student experience. International Education Journal, 5(3), 344-351. $\quad$ Retrieved from ehlt.flinders.edu.au/education/iej/articles/v5n3/hellsten/paper.pdf

Holden, S. (1981). Drama in language teaching. Essex: Longman.

Hoyt, W. T., \& Kerns, M. D. (1999). Magnitude and moderators of bias in observer ratings: A meta-analysis. Psychological Methods, 4(4), 403-424. http://dx.doi.org/doi:10.1037/1082-989X.4.4.403

Huang, J. (2005). A diary study of difficulties and constraints in EFL learning. System, 33(4), 609-621. http://dx.doi.org/10.1016/j.system.2005.04.001

Isaacs, T. (2008). Towards defining a valid assessment criterion of pronunciation proficiency in non-native English-speaking graduate students. Canadian Modern Language Review, 64, 555-580. http://dx.doi.org/10.3138/cmlr.64.4.555

Kagan, S. (1995). We can talk: Cooperative learning in the elementary ESL classroom. ERIC Digest. Washington, DC: ERIC Clearinghouse on Languages and Linguistics, May, 1995. ED 382 035. Retrieved from www.eric.ed.gov/PDFS/ED382035.pdf

Kao, S. M., \& O' Neill, C. (1998). Words into worlds: Learning a second language through process drama. London: Ablex Publishing Corporation.

Kim, S. J. (2004). Coping with cultural obstacles to speaking English in the Korean secondary school context. Asian EFL Journal, 6(3), 17-27. Retrieved from http://www.asian-efl-journal.com/Sept_04_ksj.pdf

Klinger, W. (2000). Unrehearsed speaking activities for language learning. Retrieved from www.usp.ac.jp/english/pdf/wk99-Unrehearsed.pdf

Koponen, M., \& Riggenbach, H. (2000). Overview: Varying perspectives on fluency. In H. Riggenbach (Ed.), Perspectives on fluency (pp. 5-24). Ann Arbor, MI: University of Michigan Press.

Latané, B. (1981). The psychology of social impact. American Psychologist, 36(4), 343-356. http://dx.doi.org/doi:10.1037/0003-066X.36.4.343 
Li, M. (2003). Culture and classroom communication: A case study of Asian students in New Zealand language schools. Paper presented at The Joint NZARE-AARE Conference 2003, Auckland, New Zealand. Retrieved from http://www.aare.edu.au/03pap/li03077.pdf

Liu, M., \& Jackson, J. (2008). An exploration of Chinese EFL learners' unwillingness to communicate and foreign language anxiety. The Modern Language Journal, 92(1), 71-86. http://dx.doi.org/doi:10.1111/j.1540-4781.2008.00687.x

Liu, M., \& Jackson, J. (2009). Reticence in Chinese EFL students at varied proficiency levels. TESL Canada Journal, 26(2), 65-81. Retrieved from www.teslcanadajournal.ca/index.php/tesl/article/viewFile/415/245

Long, M. H., \& Porter, P. A. (1985). Group work, interlanguage talk, and second language acquisition. TESOL Quarterly, 19(2), 207-228. http://dx.doi.org/doi:10.2307/3586827

Mak, B. S-Y., \& White, C. (1997). Communication apprehension of Chinese ESL students. Hong Kong Journal of Applied Linguistics, 2(1), 81-95. $\quad$ Retrieved from http://hkjo.lib.hku.hk/archive/files/d939fad3acd80995ad0fc1511f35d732.pdf

Maley, A., \& Duff, A. (1982). Drama techniques in language learning: A resource book of communication activities for language teachers. Cambridge: Cambridge University Press.

McCarthy, M., \& O'Keeffe, A. (2004). Research in the teaching of speaking. Annual Review of Applied Linguistics, 24, 26-43. http://dx.doi.org/doi:10.1017/S0267190504000029

Miccoli, L. (2003). English through drama for oral skills development. ELT Journal, 57(2), 122-129. http://dx.doi.org/doi:10.1093/elt/57.2.122

Mulligan, D., \& Kirkpatrick, A. (2000). How much do they understand? Lecturers, students and comprehension. Higher Education Research and Development, 19(3), 311-335. http://dx.doi.org/10.1080/758484352

O'Gara, P. (2008). To be or have not been: Learning language tenses through drama. Issues in Educational Research, 18(2), 156-166. Retrieved from www.iier.org.au/iier18/ogara.html

Podlozny, A. (2000). Strengthening verbal skills through the use of classroom drama: A clear link. The Journal of Aesthetic Education, 34(3/4), 239-275. Retrieved from http://www.jstor.org/stable/pdfplus/3333644.pdf?acceptTC=true

Rao, Z. (2001). Matching teaching styles with learning styles in East Asian contexts. The Internet TESL Journal, 7(7). Retrieved from http://iteslj.org/Techniques/Zhenhui-TeachingStyles.html

Reeve, J., Bolt, E., \& Cai, Y. (1999). Autonomy-supportive teachers: How they teach and motivate students. Journal of Educational Psychology, 91(3), 537-548. Retrieved from http://www.unco.edu/cebs/psychology/kevinpugh/motivation_project/resources/reeve_bolt_chai99.pdf

Riggenbach, H. (1991). Toward an understanding of fluency: A microanalysis of nonnative speaker conversations. Discourse Processes, 14(4), 423-441. http://dx.doi.org/doi:10.1080/01638539109544795

Rossiter, M. J., Derwing, T. M., Manimtim, L. G., \& Thomson, R. I. (2010). Oral fluency: The neglected component in the communicative language classroom. The Canadian Modern Language Review, 66(4), 583-606. http://dx.doi.org/doi:10.3138/cmlr.66.4.583

Ryan, R. M., \& Deci, E. L. (2000). Self-determination theory and the facilitation of intrinsic motivation, social $\begin{array}{llll}\text { development, and } & \text { American }\end{array}$ http://dx.doi.org/doi:10.1037/0003-066X.55.1.68

Sawir, E. (2005). Language difficulties of international students in Australia: The effects of prior learning experience. International Education Journal, 6(5), 567-580. Retrieved from http://ehlt.flinders.edu.au/education/iej/articles/v6n5/Sawir/paper.pdf

Schneier, F., \& Welkowitz, L. (1996). The hidden face of shyness. New York: Avon Brooks.

Segalowiz, N., \& Freed, B. F. (2004). Context, contact, and cognition in oral fluency acquisition: Learning Spanish in at home and study abroad contexts. Studies in Second Language Acquisition, 26(2), 173-199. http://dx.doi.org/doi:10.1017/S0272263104262027

Small, R. V., Dodge, B. J., \& Jiang, X. (1996). Dimensions of interest and boredom in instructional situations. Proceedings of selected research and development presentation at the 1996 National Convention of the Association for Educational Communications and Technology (18 ${ }^{\text {th }}$, Indianapolis). ERIC Document Reproduction Service No. ED397840. 
Smith, S. M. (1984). The theatre arts and the teaching of second languages. MA: Addison-Wesley.

Springer, S., \& Collins, L. (2008). Interacting inside and outside of the language classroom. Language Teaching Research, 12(1), 39-60. http://dx.doi.org/doi:10.1177/1362168807084493

Stern, S. L. (1980). Drama in second language learning from a psycholinguistic perspective. Language Learning, 30(1), 77-100. http://dx.doi.org/doi:10.1111/j.1467-1770.1980.tb00152.x

Stinson, M. (2007). Speaking out: An exploration of process drama and its contribution to oracy. Final Research Report for Project No. CRP 27/04 MS. Centre for Research in Pedagogy and Practice. Retrieved from http://repository.nie.edu.sg/jspui/bitstream/10497/264/1/CRP27_04MS_FinalResRpt.pdf

Stinson, M., \& Freebody, K. (2006a). The DOL Project: An investigation into the contribution of process drama to improved results in English oral communication. Youth Theatre Journal, 20, 27-41. http://dx.doi.org/doi:10.1080/08929092.2006.10012585

Stinson, M., \& Freebody, K. (2006b). Modulating the mosaic: Drama and oral language. In L. A. McCammon, \& D. McLauchlan (Eds.), Universal mosaic of drama and theatre: The IDEA04 Dialogues (pp. 193-201). Ottawa: IDEA Publications. Retrieved from http://hdl.handle.net/10497/2632

Taylor, S. E., Seeman, T. E., Eisenberger, N. I., Kozanian, T. A., Moore, A. N., \& Moons, W. G. (2010). Effects of a supportive or an unsupportive audience on biological and psychological responses to stress. Journal of Personality and Social Psychology, 98(1), 47-56. http://dx.doi.org/doi:10.1037/a0016563

Towell, R., Hawkins, R., \& Bazergui, N. (1996). The development of fluency in advanced learners of French. Applied Linguistics, 17(1), 84-119. Retrieved from http://applij.oxfordjournals.org/content/17/1/84.full.pdf

Ulas, A. H. (2008). Effects of creative, educational drama activities on developing oral skills in primary school children. American Journal of Applied Sciences, 5(7), 876-880. Retrieved from http://thescipub.com/html/10.3844/ajassp.2008.876.880

Warschauer, M. (1996). Comparing face-to-face and electronic discussion in the second language classroom. CALICO Journal, 13(2), 7-26. www.gse.uci.edu/person/warschauer_m/comparing.html

Wessels, C. (1987). Drama. Oxford: Oxford University Press.

Wong, J. K-K. (2004). Are the learning styles of Asian international students culturally or contextually based? International Education Journal, 4(4), 154-166. Retrieved from http://ehlt.flinders.edu.au/education/iej/articles/v4n4/wong/paper.pdf

Zhang, Y., \& Mi, Y. (2009). Another look at the language difficulties of international students. Journal of Studies in international Education, 20(10), 1-18. Retrieved from http://jsi.sagepub.com/content/14/4/371.full.pdf 